\title{
Preparing Preservice Teachers to Work with Diverse Student Populations: Implications for Visual Arts Teacher Education
}

\author{
Wanda B. Knight
}

\begin{abstract}
The tabric of our U.S. society is changing (Gmelch \& Parkay, 1995; Alley \& Jung, 1995). The student population in the United States classrooms is more racially and ethnically diverse than in any previous generation in Amencan history (Burstein \& Cabello, 1989).

With the increasing population of culturally diverse students entering U.S. classrooms, particularly in urban areas, and criticisms of our failure to provide successful school experiences for those students, there is a critical need for teacher education programs to equip teachers with knowledge and skills to work with diverse student populations (Burnstein \& Cabello, 1989).

Though the particular Department of Art Education being evaluated has a national and international reputation for the quality of its faculty and graduates, little seems to be known about how and to what extent its prospective teachers are being prepared to deliver discipline-based art education to today's students who represent a multiplicity of colors, languages, backgrounds and learning styles. Moreover, a review of literature signifies that research on the preparation of visual arts teachers to address the needs of diverse student populations is sorely lacking.
\end{abstract}

This investigation seeks to evaluate how and to what extent a proposed preservice visual arts teacher education program is preparing its future teachers to provide balanced discipline-based art education instruction to diverse student populations represented within their classrooms. This type of research on teacher education focuses on three domains and their linkages: antecedents or pre-existing conditions, processes, and outcomes (Nelli and Nutter, 1984). The study uses descriptive studies, participant-observational studies, and survey research methods.

Descriptive studies are utilized to provide an analysis of local antecedent conditions. Participant-observation is utilized to research processes in the implementation of the art teacher education program, whereas survey methods will be used to collect data on the outcomes of the program. Further, it is intended that a discipline-based multicultural art education curriculum model for preparing preservice teachers will be developed from this study.

\section{Statement of the Problem}

The American educational system serves an increasingly diverse student population. Students come to school speaking an array of languages and

Marilyn Zurmuehlen's Working Papers in Art Education 1996-1997 
dialects and with various levels of English proficiency. They have diverse learning, communication, and behavior styles based on their ethnic, socioeconomic, and regional backgrounds. Unfortunately, a great majority of these students tail to succeed because teachers have not been adequately prepared to provide instruction that is appropriate, inclusive, and sensitive to their students' needs (Beck, Namuth, Miller, \& Wright, 1988; Drucker, 1989).

Likewise, art teachers have not been adequately prepared to teach the increasing population of culturally diverse students entering U.S. classrooms. It has been my experience, as a parent, public school art teacher, and supervisor of preservice arts specialists, that art teachers are unable to provide balanced discipline-based art education instruction to diverse student populations represented within their classrooms, and at the same time recognize individual and cultural differences as they are reflected in learning, human relations. motivational incentives, and communication skills. Art teachers have little knowledge of how gender, culture, ethnicity, age, socioeconomic level, physical and mental capabilities, and religion can affect student learning in the educational environment.

In a newsletter of the National Council of the Accreditation of Teacher Education (NCATE), president Arthur Wise (1991) declared that states and school districts insist that every child be taught by teachers prepared to teach effectively so that every child has a genuine opportunity to learn. This admonition implies that schools and the teachers who serve in them must change. Likewise, teacher education must change (Holmes, 1986). Change can be viewed as the modification of existing conditions in response to present forces or future needs (Freiberg and Waxman, 1990). Teacher educators must provide programs that help all teachers acquire attitudes, knowledge, and skills needed to deliver education to all students equitably (Burstein \& Cabello, 1989). This, of course, implies that visual arts preservice teacher educators must examine their own programs to determine how well they are currently delivering such competencies.

This study was conceived while I was supervising preservice art teachers at a major mid-western university. The teacher candidates that I supervised and others in the program, in general, were severely limited in their experience and/or understanding from a sociodemographic perspective. Also, many of the teacher candidates appeared to be limited in their ability to perceive and cope with diversity. Recognizing that the increasing population of culturally diverse students entering U.S. classrooms would mean that our future teachers would likely teach students whose backgrounds are different from their own, I designed this study to provide insight into the nature of visual arts preservice teacher education at the research site. Specific areas of concern are as follows:

1. How and to what extent are visual arts preservice teachers being prepared to work with learners whose backgrounds are di ierent from their own and from that of others? (The focus will be on processes and experiences that help future teachers acquire the knowledge, skills, and dispositions needed to effectively work with diverse student populations in educational settings)

Marilyn Zurmuehlen's Working Papers In Art Education 1996-1997 
2. How and to what extent are visual arts preservice teachers being prepared to function non-ethnocentrically within pluralistic classrooms and schools? (The focus will be on processes and experiences that affect practices in art history, art criticism, art making, and aesthetics, and prepare future teachers to work equitably with all learners).

3. How and to what extent are visual arts preservice teachers being prepared to provide discipline-based art education instruction about the pluralism of U.S. society? (The focus will be on processes and experiences that will help future art teachers provide pluralistic curricula and instructional experiences to all learners).

\section{Significance of the Study}

The thrust toward a more substantive, comprehensive art program has required future art teachers to not only learn studio competency, art history, art criticism, and aesthetics, but to move beyond the Western tradition and address the many cultures of the world. Further, the increasing population of culturally diverse students entering U.S. classrooms, has forced many teacher education programs to begin to reconceptualize their programs toward diversity as they must equip future teachers with knowledge and skills to effectively work with diverse student populations.

Research on the preparation of visual arts teachers to work with diverse student populations has not been investigated in a sustained way. This paucity of research concerning the impact of multicultural education on prospective art teachers indicates that there is a need for more information about the scope of effective educational practice, program design, course content in the disciplines of art making, art history, art criticism, aesthetics, and field experiences and placements. The proposed study is designed to advance knowledge in the field of art education as it relates to preparing preservice teacher to address issues of diversity in art classrooms using DBAE as a platform.

\section{Review of Literature}

Reports of practicing teachers as well as national studies of teacher preparation programs (Grant \& Secada, 1990; Holmes Group, 1986) clearly indicate the lack of attention given to working with diverse populations. There is a rich body of literature on multicultural education, yet there is virtually no research on which practices are most effective in preparing preservice teachers to work with diverse learners in their classrooms (Grant \& Secada, 1990). There are many gaps left by the existing base of research and theory on multicultural education that should be addressed. My research concentrates on the multi-layered teacher training, responsibility, challenge, and opportunity and its implications of multicultural education for the art classroom.

Marilyn Zurmuehlen's Working Papers In Art Education 1996-1997 
The following three categories have been identified as significant to this study:

\section{Teacher Education Responsibility \\ 2. Teacher Education Challenge \\ 3. Teacher Education Opportunity}

The literature review focuses on the challenges associated with preparing teacher candidates for diversity because preparing them for future classrooms grows more complex as the school population becomes more diverse.

\section{Teacher Education Responsibility}

At a time when the percentages of students of color in the U.S. schools are increasing, we can no longer afford to perpetuate Western European Values and norms (Banks, 1988). This statement implies that it is the responsibility of educators to provide an education that is appropriate, inclusive, and sensitive to all students' needs (Smith, 1994; Garibraldi, 1992; Banks, 1977; Zimpher \& Ashburn, 1992; Nieto, 1992).

Schools, colleges, and departments of education have the responsibility of preparing all educators, regardless of race, to teach in culturally diverse classroom settings (Garibaldi, 1992). This responsibility includes that the culturally diverse nature of the U.S. is reflected in the curriculum, student body, faculty, and policies (Banks, 1977; Zimpher \& Ashburn, 1992).

\section{Teacher Education Challenge}

Preparing preservice teachers to address issues of diversity in their future classrooms is not easy. There are numerous challenges associated with educating teachers for diversity, therefore, I found it necessary to discuss some of them as they are bound to surface when designing curricula which will adequately prepare preservice teachers to sufficiently address the needs of diverse learners in their future classrooms.

\section{Overall Challenge}

An overall challenge is the controversial nature of multicultural education as there is a fear of radicalism in the U.S. Also, numerous published criticisms have been leveled against multicultural education (D'Souza, 1991a, 1991b; Sykes \& Billingsley, 1992; Schlesinger, 1991; Feuer; 1991). Positions on political issues define much of the debate.

\section{Defining Multicultural Education}

Multicultural education means different things to different people (Banks, 1977; Grant \& Sleeter, 1985; Sleeter \& Grant, 1988). This lack of definition contributes to multiple interpretations and competing notions, thus permitting critics to reject multicultural education or view it as a concept with no theoretical 
underpinnings. This impact and the state of confusion can be recognized in curriculum frameworks, textbooks, and teacher education programs that claim to be "multicultural" yet lack any coherent guiding philosophy.

\section{Art Education}

Art education has its own unique set of challenges. Research and reports have focused on the extreme variation of how the arts are supported and represented in schools in the U.S. (Fowler, 1988; Leonard, 1991; Viadero, 1993; Toward Civilization, 1988). Art education in general is held in low esteem (Toward Civilization, 1988; Geoghegan, 1994). In many schools art classes often are associated with play, and the amount of time relegated to the study of art is minimal at best (Grant, 1990)

\section{Discipline-Based Art Education}

There has been a broadening of the belief that art education is more than the identification and cultivation of unskilled talent in the gifted few and a taste of civilization for the rest. The discipline-based art education movement focuses upon the integration of ideas and activities derived from the disciplines of art production, art history, art criticism, and aesthetics (Clark, Day, \& Greer, 1987). The teacher education challenge associated with this broadened definition includes preparing future teachers to teach art from a much broader perspective than from which they themselves were taught (May, 1989; Cohen, 1987).

\section{Discipline -Based Art Education and Cultural Diversity}

Developing curriculum which effectively integrates cultural diversity into the art discipline, has been a long standing goal of art educators (Barbanell, 1994). However criticisms leveled against DBAE present a challenge to teacher educators who must prepare future teachers to teach diverse student populations using DBAE as a platform. For example, some researchers and art educators have questioned whether DBAE is capable of recognizing and addressing issues of diversity (Blandy \& Congdon, 1988; Collins \& Sandell, 1988); and whether it is open to multiculturalism at the conceptual level (Thurber, 1992; Grant, 1992). Others researchers and art educators, have argued that DBAE offers an avenue to help stimulate intellectual activity (Grant, 1992); addresses a wide range of learning styles (Day, 1992); and helps build self esteem (Day, 1992).

\section{Limited Frame of Reference Among Preservice Teachers}

Four years of data describing today's teacher education candidates (American Association of Colleges for Teacher Education [AACTE], 1987, 1988, $1989,1990)$ provide a proitle of future teachers that is very similar to the contemporary profile of teachers. Findings from a random sample reveal that the average preservice student is a white female from a small town or suburb who attends a college or university less than one hundred miles away from home and aims to return to a town, similar to the one from which she came, to teach middle- 
income children of average intelligence in traditional schools. Feistritzer (1983) describes the typical teacher as a white, forty-year-old married mother of two children; she is not politically active, and she teaches in an elementary school in a suburban community. Further, students mostly come from surrounding counties or from the same state (Zimpher \& Howey, 1989). Therefore, these teacher candidates are limited in their ability to perceive and cope with diversity.

\section{Broadening the Perspectives of Preservice Teachers}

Research shows that teacher education candidates are typically severely limited in their experience and/or understanding from a sociodemographic perspective, thus teacher education is challenged with broadening the perspectives of its current population (Zimpher \& Ashburn, 1992; Barnes, 1989).

\section{Reconceptualizing Teacher Education Toward Diversity}

Educational research has shown that educators acknowledge the ideals of cultural pluralism, but that, traditionally educational institutions have not adopted pedagogy to reflect the needs of students from diverse cultural, socioeconomic backgrounds, and racial and ethnic groups (Barton \& Wilder, 1964; Winfield, 1991). Additionally, schools have made little progress in incorporating information into curricula concerning the achievements of traditionally underrepresented groups as a Euro-centric bias has dominated the American educational system. Changing schooling to better serve children from diverse backgrounds, particularly African American students, is a goal that the American public school system has been reluctant to accept (Maeroff, 1989). Garcia and Goebel (1985) assert that the challenge associated with reconceptualizing teacher education toward diversity is that new plans for teaching about differences has been formulated largely through the eyes of mainstream scholars and historians. As a consequence of this mainstream perspective on diversity, Green (1983) observed that those not in the mainstream remain invisible.

A further challenge to reconceptualizing teacher education toward diversity is that the process of education occurs within a social framework (Apple, 1979; hooks, 1994); and is designed to perpetuate the aims of society (Apple, 1979; hooks, 1994; Katz, 1975;

Bowles \& Gintis, 1976, Giroux, 1983).

\section{Curriculum}

There is a rapidly growing tendency among art education faculty and students to reject traditional curriculum and course content as "androcentric" and "Eurocentric," recognizing that the art curriculum in higher education has been dominated by a Westurn European, male-focused perspective. Proposals for reconceptualizing teacher education include suggestions for adding courses or infusing courses with multicultural perspectives and changing the nature of field experiences to expose teacher candidates to culturally diverse school settings (Banks, 1994; Banks, 1993; Gay, 1988).

Marilyn Zurmuehien's Working Papers In Art Education 1996-1997 


\section{Changing Attitudes of Teacher Candidates}

Teachers' attitudes are crucial to their ability to convey multicultural content. Teachers' attitudes affect their behavior toward children, which in turn, has an effect on the self-esteem and performance of children. Moreover, children's attitudes and beliefs are influenced by their teachers as they directly affect their interactions with and behavior towards others unlike themselves. Such interactions can be positive and growth enhancing, or they can be negative and result in hate, distrust, and rejection (Pang, 1988). It is imperative that future art teachers be prepared in ways that will make them more accepting of diversity.

\section{Expanding the Cultural Diversity of Teacher Education}

If teacher education of the future is to present a model of the positive incorporation of racial, ethnic, and gender diversity, its student body and faculty must become more culturally diverse. Green (1989) offers a variety of strategies designed to recruit diverse student and faculty populations in teacher education programs.

\section{Funding}

The difficulties associated with culturally homogeneous teacher education will not be adequately addressed without linancial assistance from federal, state, and private sources. Peseau(1990) declares that most colleges and universities interested in curriculum reform must do so with limited funding from within their institutions. He further note that most institutions of higher education are in a state of crisis, meaning that they are distinguished by inadequate resources and retrenchment threats. Clearly, such conditions impact programs of research and training associated with the challenges of preparing teachers for multicultural populations.

\section{Teacher Training Opportunity}

The cultural, racial, ethnic, and religious diversity that Western nations are facing is a challenge. It is a challenge because ethnocentrism, intergroup hostility, and other forms of conflict erupt when groups with divergent values and cultures interact. Challenges can become opportunities if educational leaders "respond positively to the challenges posed by this increased diversity" (Banks, 1987, p.62; hooks. 1994).

If the educational profession does not exercise its opportunity to participate in the formulating and restructuring of government policies affecting education, "it will not only leave the destiny of American education in the hands of others, it will be abdicating a good part of its professional responsibility to our society as well." (Moinar, 1987, p.6). Finally, Molnar captures the challenge succinctly: "We cannot escape our responsibility for the world we turn over to our students" (p. 6). 


\section{Methodology}

Qualitative investigations assume that reality is affected by personal interactions and perceptions, and beliefs (Merriam, 1991). Conceptually, teacher education is a multifaceted, layered, interactive, and ongoing mix of people. roles, ideas, contexts, beliets, and activities; thus, qualitative methods of research have been employed to obtain data about how preservice visual arts teachers at the research site are being prepared to meet the needs of diverse student populations.

This research focuses on three domains and their linkages: antecedent conditions, processes, and outcomes (Nellie \& Nutter, 1984). Antecedent conditions refer to any condition existing prior to teaching and learning that may relate to the outcomes (Stake, 1976) (e.g. student selection, program structure, student and faculty characteristics, physical environment, political/social context). Processes refer to those practices used to educate teachers: those essential aspects associated with the actual delivery of the teacher education experience. Outcomes refer to those learned or evoked behaviors exhibited by teachers following participation in an education intervention (Nellie \& Nutter, 1984). This would include both teacher behavior and student reaction to the behavior.

Nellie and Nutter (1984) indicate that descriptive studies are the most basic kind of research on teacher education. These studies will be utilized to describe the program and local antecedent conditions. Local antecedent conditions will be described in terms of students, faculty, and resources.

Participant-observation is critical to this study as observation is fundamental and critical in all qualitative inquiry (Marshall \& Rossman, 1995). This phase of my research involved observation of all core and teacher preparation courses in the Department of Art Education at the research site, during the 19951996 academic year. My intent was to study the processes in the implementation of the art teacher education program. By directly observing the program's operations and activities, I am better able to understand the context within which the program operates. Also, by being on-site, I have less need to rely on prior conceptualizations of the program. Observational data described the setting, the actions that took place in the settings, and the people who participated in those activities.

The next phase of my research will be to collect data, via questionnaire on the outcomes of the program from the program participants (faculty, preservice teachers, university supervisors, and cooperating teachers). The close-ended and open-ended questionnaire will elicit information related to the respondents' general perceptions of the undergraduate and graduate art teacher preparation program at the research site. The data collected will help answer the questions that give direction to the study.

Marilyn Zurmuehlen's Working Papers In Art Education 1996-1997 


\section{Conclusion}

The demographics of the student population are rapidly changing, while the demographics of the teaching force are not (Zimpher \& Ashburn, 1992). When we speak of educating teachers for diversity, we are speaking of educating, for the most part, white, middle-class females (Feistritzer, 1983: Zimpher \& Ashburn, 1992).

It is incumbent upon art teacher educators to recognize the new demographics and identify and respond to their educational implications as they prepare their future art teachers to work with diverse student populations in American schools. Such a lack of preparation will likely result in teachers being woefully unprepared and students being miseducated.

\section{References}

Alley, R. \& Jung, B. (1995). Preparing teachers for the 21st century in O'Hare, J. \& Odell, S. (Eds.) Educating Teachers for Leadership and Change, Thousand Oaks, CA.: Corwin Press.

American Association of Colleges for Teacher Education. (1987). RATE I.

Teachingteachers: Facts and figures. Washington, DC:

American Association of Colleges for Teacher Education.

American Association of Colleges for Teacher Education. (1988). RATE II.

Teaching teachers: Facts and figures. Washington, DC:

American Association of Colleges for Teacher Education.

American Association of Colleges for Teacher Education. (1989). RATE III. Teaching teachers: Facts and figures. Washington, DC: American Association of Colleges for Teacher Education.

American Association of Colleges for Teacher Education. (1990). RATE IV. Teaching teachers: Facts and figures. Washington, DC: American Association of Colleges for Teacher Education.

Apple, M. (1979). On analyzing hegemony. The Journal of Curriculum Theorizing, 1(10-43)

Banks, J. A. (1977). The implication of multicultural education for teacher education. In F. Klassen, \& D. Gollnick (Eds.) Pluralism and the American teacher: Issues and case studies. Washington, DC: American Association of Colleges for Teacher Education.

Banks, J. A. (1988). Ethnıcity, class, cognitive, and motivational styles: Research and teaching implications. The Journal of Negro Education, 452-466. 
Banks, J. A. (1993). Approaches to multicultural curriculum reform. In J. A. Banks \& C. A. M. Banks (Eds.), Multicultural education issues and perspectives (2nd ed., pp. 195-214). Boston: Allyn and Bacon.

Banks, J.A. (1994). Multiethnic education: Theory and practice. (3rd ed.). Boston, MA: Allyn and Bacon..

Barbanell, P. (1994). Multicultural art education: Many views, one reality. The Journal of Multicultural and Cross Cultural Research in Art Education, 20. 26-32.

Barnes, H. L. (1989). Structuring knowledge for beginning teaching. in M. Reynolds (ed.), Knowledge base for the begining teacher. Elmsford, NY: Pergamon Press.

Barton, A. H., and Wilder, P. E. (1964). Research and practice in the teaching of reading: A progress report. In $M$. B. Miles (ed.), Innovations in education. New York: Teachers College Press.

Beck, Namuth, Miller \& Wright L. (1988, May). Saving our schools: A nation still at risk. Newsweek, pp. 54-55.

Blandy, D. \& Congdon, K. (1988). Prologue. Journal of Multicultural and Cross-cultural Research in Art Education, 6(1), 3-11.

Bowles, S., and Gintis, H. (1976). Schooling in Capitalist America. New York: Basic.

Burstein, N.D., \& Cabello, B. (1989, Sept-Oct). Preparing teachers to work with culturally diverse students: A teacher education model. Journal of Teacher Education, 54(5), 9-16.

Cohen, K. (1987). Implications of discipline-based art education for preservice art education. The preservice challenge: Discipline-based art education and recent national reports on higher education Los Angeles, CA.: The Getty Center for Arts Education. 5-8.

Collins, G. and Sandell, R. (1988). Informing the promise of DBAE: Remember the women, children and other folk. Journal of Multicultural and Cross-cultural Research in Art Education.

Clark, G., Day, M., Greer, E.D. (1987). Discipline-based art education. Becoming students of art. Journal of Aesthetic Education, 21(2), 129-196.

Day, M. (1992). Cultural Diversity and discipline-based art education. Discipline-based art education and cultural diversity. Los Angeles, CA.: The Getty Center for Education in the arts. 23-25. 
D'Souza, D. (1991a). Illiberal education. The Atlantic, 267, 51-79.

D'Souza, D. (1991b). Illiberal education: The politics of race and sex on campus. New York: The Free Press.

Drucker, P. F. (1989, May). How schools must change. Psychology Today, pp. $18-20$

Feistritzer, C.E. (1983). The American teacher. Washington, DC: National Center for Education Information.

Feuer, L. (1991). From pluralism to multiculturalism. Society, 29(1), 19-22.

Fowler, C. (1988). Can we rescue the arts for our children? Coming to our senses - 10 years later. New York: ACA Books.

Frieberg, J. H., \& Waxman, H.C., (1990). Changing teacher education. Handbook of Research of Teacher: New York, Macmillan.

Garcia, J., and Goebel, J. (1985). A comparative study of the portrayal of black Americans in selected U.S. history textbooks. Negro educational Review, 36, 118-127.

Garibaldi, A. M., (1992). Preparing teachers for culturally diverse classrooms. In Dilworth, M. E. (Ed.), Diversity in teacher education: New expectation s. (pp. 23-39). San Francisco: Jossey Bass.

Gay, G. (1988). Designing relevant curricula for diverse learners. Education and Urban Society, 20,327-340.

Geoghegan, W. Re-placing the arts in education. (1994, February). Phi Delta Kappan, pp. 456-458.

Giroux, H. (1983). Theory and Resistence in Education. South Hadley, MA: Bergin and Garvey.

Gmelch, W. \& Parkay, F. (1995). Changing roles and occupational stress in the teaching profession in O'Hair, J. \& Odell, S. (Eds) Educating Teachers for Leadership and Change, Thousand Oaks, CA. Corwin Press.

Grant, C.A., \& Secada, W.G. (1990). Preparing teachers for diversity. In Houston, W. R. (Ed.), Handbook of Research on Teacher Education, (pp. 403-422). New York: Macmillan.

Grant, C.A. (1990). So you want to infuse multicultural education into your discipline? Case Study: Art Education. The Educational Forum, $54,18-290$. 
Grant, C.A. (Ed.). (1992). Research and Multicultural Education: From the Margins to the Mainstream. Washington, DC: The Falmer Press.

Grant, C. \& Sleeter, C. (1985). The literature on multicultural education: Review and analysis. Educational Review, 37(2), 97-118.

Grant, C. \& Sleeter, C. (1989). Turning on learning: Five approaches for multicultural teaching plans for race, class, gender, and disability. Columbus, $\mathrm{OH}$ : Merill.

Green, M. (1983). Openings to possibility: The common world and the public school. In J. Frymer (ed.), Bad times, good schools. West Lafayette, In: Kappa Delta Phi.

Green, M. (1989). Minorities on campus: A handbook for enhancing diversity. Washington, DC: American Council on Education.

Holmes Group. (1986). Tomorrows teachers: A report of the Holmes Group. East Lansing, Ml: Author.

hooks, b. (1994). Teaching to Transgress. Boston: South end Press.

Katz, M. B. (1975). Class, Bureaucracy, and schools: The illusion of educational change in America. (Rev. ed.) New York: Praeger.

Leonard, C. (1991). The status of arts education in American public schools: Report on a survey conducted by the National Arts Education Research Center at University of Illinois. Urbana, IL: Council for Research in Music education (University of lilinois).

Maeroff, G. I. (1988). Withered hopes, stillborn dreams: The dismal panorama of urban schools. Phi Delta Kappan, May, 633-638.

Marshall, C. \& Rossman, G. (1995). Designing qualitative research. (2nd Ed,). Thousand Oaks, CA: Sage.

May, W. T. (1989). Teachers, teaching in the workplace: Omissions in curriculum reform. Studies in Art Education, 30(3), 142-156.

Merriam, S. B. (1991). Case study research in education: A qualitative approach. San Francisco: Jossey-Bass Publisher

Molnar, A. (1987). Curriculum theory. Washington, DC: Association for Supervision and Curriculum Development.

Nelli, E. \& Nutter, N. (1984). A model for evaluating teacher education programs. Washington, DC: American Association of Colleges for Teacher Education. 
Nieto, S. (1992). Affirming diversity: The socialpolitical context of multicultural education. White Plains, NY: Longman.

Pang, V. (1988). Ethnic prejudice: still alive and hurtiul. In N. M. Hildago, C. L. McDowell, and E.V. Siddle (ed.), Facing Racism in Education. ( $p p$ 28-32).

Cambridge, MA: Harvard Educational Review.

Peseau, B. (1990). Financing teacher education. In R. Houston (Ed.). Handbook of Research on Teacher education.

Schlesinger, A. M. (1991). The disuniting of America. New York: Norton.

Sleeter, C. \& Grant, C. (1988). An analysis of multicultural education in the United States. Harvard educational Review. 57. 421-44.

Smith, P. (1994). Multicultural issues: Dilemmas and hopes. Art Education, $47(4), 13-17$.

Stake, R. E. (1976). Evaluating educational programs: The need and the response. Paris: Organization for Economic Co-operation and Development.

Sykes, C., \& Billingsley, K. L. (1992). Multicultural matia. Heterodoxy, 1(15), 1, 4-6.

Thurber, F. (1992). Cultural diversity and DBAE: The challenge of one world and multiple visions. Discipline-based art education and cultural Diversity. Los Angeles, CA.: The Getty Center for Education in the Arts. 28-31.

Toward Civilization: Overview from a report on arts education ( $S / N$ 036-000-0051). (May, 1988). Washington, DC: National Endowment for the Arts - US Government Printing Office.

Viadero, D. (March, 1993). Standards seen as steps to insuring arts education. Education Week. p. 33.

Wintield, L. F. (1991). Resilience, schooling, and development among Atrican American youth: A conceptual tramework. Education and Urban society, 24(1), 5-14.

Zimpher, N.L. \& Howey, K. (1989). The RATE project: A profile of teacher education students. Journal of Teacher Education, 40(6), 27-30.

Zimpher, N. L. \& Ashburn, E. A. (1992). Countering parochialism in teacher education. In Dilworth, M. E. (Ed.). Diversity in teacher education: New expectations. (pp. 40-62). San Francisco: Jossey Bass Publishers. 